Cad. Benjaminianos, Belo Horizonte, v. 15, n. 1, p. 53-77, 2019

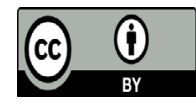

\title{
1968, o ano que ainda não começou - Comentário ao filme Mourir à trente ans, de Romain Goupil
}

\section{8, the Year that Has Not Yet Begun-Commentary on Romain Goupil's film Mourir à Trente Ans}

\author{
Virginia de Araujo Figueiredo \\ Universidade Federal de Minas Gerais (UFMG), Belo Horizonte, Minas Gerais / Brasil \\ virfig1955@gmail.com
}

Resumo: O texto que se segue é um comentário ao filme de Romain Goupil, Morrer aos trinta anos, e tece algumas considerações sobre o Maio de 1968 na França. Além disso, instigada pelo organizador da Mostra, Pedro Rena, tentei estabelecer um paralelo entre o Maio francês e as manifestações de 2013 no Brasil, cujas consequências talvez ainda estejam repercutindo até hoje, no Brasil pós-eleições de 2018.

Palavras-chave: Maio 68 na França; Manifestações de 2013 no Brasil; Goupil; Arte; Política.

Abstract: This text is a commentary on Romain Goupil's film Mourir à trente ans, and aim to consider some events of May 1968 in France. In addition, instigated by Pedro Rena, the Seminar's organizer, I tried to establish a parallel between the French May and the manifestations of 2013 in Brazil, whose consequences may still be reverberating to this day in Brazil after the 2018 elections.

Keywords: May 68; Manifestations 2013 in Brazil; Goupil; Art; Politics.

Para esses outros [que continuam insistindo (...) que um outro mundo é possível (...)] o evento absoluto que foi 68 ainda não terminou, e ao mesmo tempo talvez sequer tenha começado, inscrito como parece estar em uma espécie de futuro do subjuntivo histórico (VIVEIROS DE CASTRO, 2018, p. 99-100). 


\section{Introdução e resumo do filme}

Perguntei-me o motivo do convite, o qual confesso hesitei em aceitar: terá sido pelo fato de eu ser professora de filosofia? E, mais especificamente, professora na área de Estética e Filosofia da Arte, no entanto, com zero de conhecimento ou expertise acerca da imagem e do cinema? Terá sido pela minha idade? Pois, conforme divulgado no Jornal Pampulha de 26/05/2018, Juca Ferreira, secretário municipal de cultura de $\mathrm{BH}$, que comentou ontem o filme de João Moreira Salles, também foi convocado, entre outros motivos, como uma espécie de testemunha ocular da história. No Jornal, Pedro Rena explicava o convite: "O Juca viveu tudo isso. Foi exilado na década de 70, ou seja, ele viu o golpe 64 e depois o maio 68 etc." Então, continuo: o convite terá sido motivado pela minha idade, por eu ter podido ser como Juca Ferreira, uma espécie de testemunha ocular dos acontecimentos do maio 68? Respondendo já frustrando essa expectativa: não, infelizmente, não participei de maio 68 ! Tinha 12 anos, e fiquei de fora! Não era sequer secundarista como Juca Ferreira, apenas 5 anos mais velho do que eu, ou como o cineasta Romain Goupil, do filme Morrer aos 30 anos, que também tinha 17 anos, em 1968. Ambos tiveram uma possibilidade histórica bem diferente da minha, da qual resultou inevitavelmente outra experiência de vida individual e coletiva. Só me tornei militante muito tempo depois, já na década de 1970, precisamente a partir de 1974, quando entrei na universidade e aderi ao movimento estudantil da época. Em momentos histórica e politicamente intensos como esse, faz muita diferença ter um ano ou dois de idade, a mais ou a menos! Silvio Tendler (1950) também se referiu a essa pequena diferença de idade, comparando-se à cineasta Lúcia Murat (1949)... Ou seja, de apenas um ano! ${ }^{1} \mathrm{E}$ atribuiu, a essa ínfima diferença de idade, os destinos tão distintos: o dele, que se tornou cineasta, e o dela, que aderiu à luta armada contra a ditadura brasileira. Ele falou uma coisa engraçada

\footnotetext{
${ }^{1}$ No dia 25/05/2018, saindo da sessão do filme $O$ processo, no Espaço Itaú de Botafogo, RJ, vimos, na Livraria ao lado do cinema, o anúncio de uma mesa-redonda sobre maio 68 com Silvio Tendler e Lúcia Murat. Entramos. Silvio Tendler começou sua fala desfiando uma longa lista de filmes brasileiros que participaram do $4^{\circ}$ Festival de Brasília, em fevereiro daquele ano de 68. Apesar da repressão política e da censura, havia uma inegável efervescência cultural, não só no cinema, mas também no teatro, com a encenação de Rei da Vela, Galileu Galilei, assim como na música, nos festivais da canção da TV Record.
} 
ao definir aqueles anos 1960: "naquela época, havia apenas duas opções de vida: ou você entrava na luta armada ou você virava cineasta." Ele completou, dizendo que tinha tido muita sorte, de poder ter se tornado cineasta, pois jamais teria sido capaz de pegar num revólver. Faria a mesmíssima confissão pública a meu respeito quanto à luta armada. Como Silvio Tendler, jamais teria coragem de pegar num revólver. Ele fez ainda uma observação interessante, a qual nunca tinha ouvido, a de que o Cinema Novo discutiu exatamente essa alternativa e que o grande exemplo dessa discussão havia sido Terra em transe. Bem, não conheço suficientemente o Cinema Novo para saber se ele tem (ou não) razão. De qualquer modo, o que me interessa aqui é a importância do cinema e de sua relação com a política, pois isso também foi sublinhado no filme de Goupil. Logo na primeira parte, o personagem Romain, encarnado pelo próprio diretor ainda adolescente, fala: "A política começava a controlar o nosso tempo. Sobrava pouco tempo para o cinema. Por outro lado, não conseguia mais pensar num cinema sem política."

Depois desta brevíssima introdução, faço um pequeno resumo do filme de Romain Goupil, Morrer aos trinta anos, uma espécie de documentário lançado ${ }^{2} \mathrm{em} 1985$. Como numa dedicatória, o filme começa triste, quase fúnebre, com uma tela preta, na qual se estampam os nomes de vários jovens que morreram muito cedo, justificando o título: Anne Sylvie (suicida), Dominique (acidente), Pierre Louis (suicida), Michel Recanati (suicida). Desses jovens amigos, que morreram precocemente, o filme vai focalizar Michel Recanati, o maior amigo do diretor, que se suicidou em 23 de março de 1978. O narrador nos conta que foi a notícia do suicídio de seu amigo que o levou à decisão de juntar todos os registros que fizera ao longo dos anos 1964 a 1973 e transformá-los num filme em homenagem a seus amigos, especialmente, Michel. O filme é, portanto, a história desses jovens, sobretudo Romain e Michel, estudantes secundaristas na época, que participaram intensamente dos acontecimentos de maio 68 e depois, até precisamente 21/06/1973. ${ }^{3}$ Junto com Michel, Romain foi

\footnotetext{
${ }^{2}$ Embora o filme só tenha vindo a público em 1985, a história que nele se conta começa em 1964, com o "Bando dos Coyottes", formado pelos três amigos Romain, Coyotte e Baptiste. São registros feitos por uma câmera $8 \mathrm{~mm}$; pequenos filmes completamente nonsense: da velhinha que despenca do alto do prédio, ao suicídio do amigo Coyotte, que ressuscita nas férias do ano seguinte (1965).

${ }^{3}$ Voltarei a essa data mais adiante.
} 
um dos criadores do Comité d'Action Licéenne (CAL). Necessário dizer que esses comitês tiveram um papel importantíssimo no maio 68, uma espécie de vanguarda do movimento secundarista na França (na Wikipedia, informa-se que, em 1967, havia mais de 400 CALs!). Abrindo parêntese aqui, talvez se possa estabelecer uma equivalência com o Brasil de 2013, quando também o movimento dos secundaristas, ocupando as escolas, posicionou-se nitidamente na vanguarda, digamos assim, criativa do outro movimento (conhecido como "Manifestações de 2013"), que depois, infelizmente, foi capturado pela direita.

Mas voltemos ao resumo do filme que, como disse, apesar de começar e terminar de modo muito sombrio, uma vez acabada a seção inicial do obituário, assume um tom que ousaria dizer ser alegre! $!^{4}$ Aliás, foi uma cena feliz e emocionante que me levou a aceitar o convite do Pedro e da Natacha para comentar o filme! Descrevo a cena: vemos um aluno que se levanta na sala de aula e ouvimos um grito: "Allez! Dépêchezvous!" ("Vamos! Apressem-se!"). Grito que ressoa com uma força irreprochavelmente histórica! Chamando os jovens para tomarem com urgência as ruas de Paris! As cenas que se seguem mostram a corrida dos estudantes pelas escadarias dos colégios, atendendo à convocação para uma das primeiras manifestações do maio (dia 6) 68 em Paris. Absolutamente contagiante, arrepiante a cena dessa corrida, acompanhada por um trecho, cuidadosamente escolhido, da ópera Carmen de Bizet, cantado por um coro de crianças, La cloche a sonnée. Assim, contrariando o título proposto para nossa mesa, "Revolta e Melancolia", ouso dizer que Morrer aos trinta anos, apesar do melancólico título, do início e dos minutos finais, é um filme alegre! Como talvez tenha sido o "belo mês de maio em Paris"!

Por causa da emoção alegre que essa cena provocou em mim que estou hoje (31/05/2018) aqui, pois acredito mais na alegria do que na melancolia! A luta política tem de estar mais próxima da festa que do funeral. Tem de estar atenta e comemorar este mundo, no qual vivemos, e não o mundo dos mortos. Então, é a isso que temos de nos "manter fiéis"! Nos termos do conselho hölderliniano, temos de nos

\footnotetext{
${ }^{4}$ Compartilho essa opinião com Patrick Pessoa ("Sísifo infeliz No intenso agora". Revista Viso, Cadernos de Estética Aplicada, nº 23, 2018. http://revistaviso.com.br/ visArtigo.asp?sArti $=272$ ).

5 "Joli mois de mai", por mais estranho que pareça, foi uma frase exclamada por um líder direitista que aparece no filme, no trecho final da $3^{\mathrm{a}}$ parte. Num ato de verdadeira coragem, Romain, infiltrado, filma o comício de extrema-direita (ocorrido em 1969?).
} 
manter fiéis à "infidelidade dos deuses". ${ }^{6}$ Mas o que quer dizer essa aparentemente obscura expressão "a infidelidade dos deuses"? A meu ver, ela não quer dizer outra coisa senão que a nossa vida, a nossa luta, que é constante e política, se dá aqui, neste mundo, nesta terra, a dos mortais, e não no outro mundo suprassensível, dos já mortos ou dos imortais! E tenho quase certeza, hoje mais do que nunca, que é isso o que significa aquela obscura expressão da "infidelidade divina"! Afinal de contas, Hölderlin estava dizendo, com as suas palavras, a mesma coisa que Kant! Este filósofo, o mais sóbrio entre todos, sempre nos advertiu que nada podemos conhecer sobre estas questões - existência de Deus, imortalidade da alma etc. -, que são perguntas, na verdade, extravagantes e indiscretas, que "nos impelem para além dessa vida", numa palavra: são metafísicas. E, porque a razão (teórica) se recusa a dar uma resposta, devemos abandonar "a infecunda especulação", para nos voltarmos para o seu "uso prático". 7 O que provavelmente Hölderlin chamou de a "volta categórica" (kategorische Umkehr). ${ }^{8}$ A razão vira

${ }^{6}$ HÖLDERLIN, 2008, p. 79: “o deus e o homem - para que o curso do mundo não tenha lacuna e não desapareça a memória dos celestiais - se comunicam na forma da infidelidade esquecedora de tudo, pois a infidelidade divina é o que há de melhor para lembrar."

${ }^{7}$ KANT, 1980, p. 209: "Por isso, não há nenhuma psicologia racional como doutrina que aumente o nosso autoconhecimento, mas somente como disciplina que neste campo põe insuperáveis limites à razão especulativa, de um lado para que ela não se lance no seio de um materialismo sem alma, e de outro para que não se perca vagando num espiritualismo sem base para nós na vida; tal disciplina, muito antes, recorda-nos que consideremos esta recusa da nossa razão a fornecer uma resposta satisfatória às questões indiscretas que nos impelem para além dessa vida, como uma sua advertência a que voltemos o conhecimento de nós mesmos de uma infecunda e extravagante especulação para a sua aplicação num fecundo uso prático. Tal uso, embora se dirija sempre a objetos da experiência, toma de uma origem mais alta os seus princípios e determina o comportamento, como se o nosso destino se estendesse para além da experiência, e por conseguinte para além desta vida."

${ }^{8}$ HÖLDERLIN, 2008, p. 79: "Nesse momento, o homem esquece de si e de deus, e se afasta [umkehren], certamente de modo sagrado, como um traidor. No limite extremo da dor, nada mais resta senão as condições do tempo e do espaço.” Tradução ligeiramente modificada.

Pedro Süssekind faz uma nota acerca da tradução de umkehren: "que tem o sentido de voltar, retornar, fazer a volta, regressar, inverter, dar as costas, virar o rosto. Optamos, algumas vezes, pelos termos 'afastar-se' para o verbo umkehren, e 'afastamento' para 
a face, vira o rosto, abandona a esfera teórica e se volta para a prática, para a ação, acolhendo os seus limites, que "nada mais são do que as condições do tempo e do espaço". Agimos neste mundo, apenas como se nossas almas fossem imortais! Mas, apesar de não sermos imortais, somos inexoravelmente responsáveis pelo futuro das nossas ações, pelo que nossas ações são capazes de desencadear no futuro. Essa ação lançada para o "futuro do subjuntivo histórico", segundo a feliz e acertada expressão de Viveiros de Castro; ou ainda, como a definiu precisamente Sartre, na famosa entrevista que fez a Daniel Cohn-Bendit, a ação dos soixante-huitards, ${ }^{9}$ como sendo uma "ampliação do campo do possível" (SARTRE; COHN-BENDIT, 2008, p. 25). ${ }^{10}$ A obrigação, o dever, se se preferir: o "imperativo categórico" de uma geração consiste em "ampliar o campo do possível" das gerações futuras, daqueles que estão por vir! Essa é a tarefa e a missão de toda e qualquer geração.

\section{Dos cruces}

Estan clavadas dos cruces

En el monte del olvido

Por dos amores que han muerto

Sin haberse comprendido

(Carmelo Larrea/Milton Nascimento)

Teria, pelo menos, duas opções aqui: 1) se não quisesse ser polêmica, bastaria seguir o fio teórico e/ou filosófico das intrínsecas relações entre arte e política, as quais, parafraseando um famoso verso do poeta Hölderlin, poderiam ser assim resumidas: é politicamente que

\footnotetext{
o substantivo Umkehr, mas, outras vezes, pelos termos 'retorno' e 'retornar' quando o sentido exigia. Lacoue-Labarthe assinala que, no alemão da época, essas palavras remetem à Revolução Francesa e têm o sentido geral de subversão, revolta.

${ }^{9}$ Os participantes do Maio 68.

${ }^{10}$ Conforme nota sobre os autores no final do livro: "Daniel Cohn-Bendit foi líder do movimento estudantil 22 de março, que daria início ao que ficou conhecido como Maio de 68." Nasceu na França, filho de pais alemães, fugidos do Nazismo. Em 1968, estudava Sociologia na Universidade de Nanterre (Paris X). Muito mais tarde, tornouse deputado europeu.
} 
a arte habita este mundo. ${ }^{11}$ 2) A outra opção, bem mais polêmica, que resolvi seguir foi sugerida e publicada no jornal Pampulha, já citado, do dia 26 de maio: a de fazer um paralelo entre "as manifestações e atos nas ruas de inúmeras cidades há 50 anos" e "os movimentos decorrentes do Junho de 2013 no Brasil." E um dos organizadores do evento, Pedro Rena, continuou: "Há um gesto de resgatar a história para enxergar o presente. A mostra serve menos para estabelecer uma palavra final ou compreender o processo, definindo 'foi isso, foi aquilo', mas para pensar o que reverbera hoje em dia".

Foi mais ou menos assim que, em 31/05/2018, comecei meu texto apresentado no evento "68 e depois". Hoje, quase seis meses depois, no mesmo fatídico ano de 2018 (que bem poderia nos ter dado a graça de acabar antes do dia 7 de outubro!), retomo esse comentário num contexto que não hesito em qualificar de "trágico" ou "catastrófico" para o nosso país! Durante o período que precedeu o segundo turno, formulei da seguinte maneira o quadro diante do qual considerei que o povo brasileiro se encontrava. Falei para muita gente que nos encontrávamos "entre o céu e o inferno", entre um projeto de país que tentaria prosseguir com as políticas públicas de combate às terríveis injustiças e desigualdades que marcam a nossa sociedade ou uma falta total de projeto de país, uma ignorância profunda sobre nós, a não ser a violência, o ódio, a vingança, o preconceito, ou seja, tudo do que não precisamos! E a terrível e inesperada surpresa, o estarrecimento (!!) de ver uma boa parte do povo brasileiro escolher o inferno! Muito difícil, dificílimo compreender!

Mesmo não sendo uma teórica política ${ }^{12}$ e certamente não tendo a menor competência acadêmica para escrever sobre o tema, não posso ignorar ou ficar indiferente ao tsunami devastador dos acontecimentos políticos neste ano. Seria uma imperdoável omissão histórica. E como entender o que está acontecendo hoje exige uma volta a 2013, aceitei o perigoso desafio de procurar estabelecer um paralelo entre os anos $1968 \mathrm{e}$

${ }^{11} \mathrm{O}$ famoso verso que parafraseio está no poema tardio de Hölderlin, "In lieblicher Bläue blühet" (No azul adorável, floresce): "Voll Verdienst, doch dichterisch,/ Wohnet der Mensch auf dieser Erde." (Cheio de méritos, mas é poeticamente que o homem habita esta terra.)

${ }^{12} \mathrm{O}$ ex-presidente do Uruguai, José Mujica, reivindicou recentemente, numa entrevista feita por Pedro Bial, em 5 de maio de 2017, divulgada no YouTube (cf. https://www. youtube.com/watch? $\mathrm{v}=\mathrm{Hhs} 982 \mathrm{WCHdo}$ ), o direito de falar como "homem do senso comum". 
2013. Para retroagir até as manifestações de 2013, tentando compreendêlas, contei com a preciosa assistência do Mestre em Comunicação Social Pedro Veras, ${ }^{13}$ quem, como muitos jovens, delas participou ativamente. A ele devo (e por isso agradeço aqui publicamente) algumas formulações muito atentas e cuidadosas sobre este inegavelmente importante momento histórico. Foi ele que me chamou a atenção, pela primeira vez, não só para a multiplicidade da agenda que estava em jogo, assim como para o papel das redes sociais na mobilização social. A novidade deste último aspecto tornou totalmente imprevisível o desdobramento do movimento. O poder das redes sociais, a princípio ambíguo, revelouse (em outubro de 2018) bastante terrível e assustador. A promessa de democratização que todos consideravam estar ali embutida mostrou-se apta a produzir um insuportável paradoxo, que consistiu em, através do mecanismo democrático por excelência, que é o voto, eleger o candidato exatamente antidemocrático! Aquele capaz de destruir e aniquilar a própria democracia, se não houver resistência da esquerda inteira, unida, chamada "progressista", necessária e urgentemente, no meu modo de ver, relevando (não no sentido de "tornar saliente", mas sim no seu uso menos comum, que é o de "atenuar e permitir") e compondo com as diferenças!

Poderia situar-me neste lugar que foi designado como uma "antiga" esquerda, ou mesmo, talvez, como muito apropriadamente escreveu Caetano Veloso, em Verdade Tropical, referindo-se a Roberto Schwarz,

\footnotetext{
${ }^{13}$ Fiz um convite (não aceito, infelizmente) a Pedro Veras, meu filho, para participar da escrita deste ensaio, inspirando-me no próprio evento "68 e depois", organizado pela bonita parceria entre mãe e filho: Natacha e Pedro Rena. Essa inspiração também se deveu à urgência dessa relação, sempre essencial, mas que se tornou crucial no nosso momento histórico, a qual consiste no diálogo entre as diferentes gerações, sobretudo para falarmos da herança e do legado das múltiplas e distintas esquerdas, para que não morram sin haberse compreendido. É necessário prestar muita atenção e tomar extremo cuidado com o passado! E nunca esquecer da gratidão, pois é sempre bom lembrar que "pensar é agradecer"! Essa frase célebre do poeta romeno Paul Celan - "Denken ist danken" - que amo repetir. O diálogo frutífero entre gerações tem de ser atravessado pelo sentimento de gratidão.
} 
como uma esquerda "desconfiada" (PENNA, 2017) ${ }^{14}$ (antecipando... Desconfiada do movimento que tomou as ruas em 2013). ${ }^{15}$ Explico-me: Apesar de ser de 2017, só muito recentemente li este livro admirável e inspirador de João Camillo Penna, $O$ tropo tropicalista.... É um livro importantíssimo! Ele trata da interpretação não muito favorável que Roberto Schwarz fez do Tropicalismo e, especialmente, do artista Caetano Veloso... Como já disse antes, decidi encarar a tentativa polêmica de estabelecer um paralelo entre 1968 e 2013 e, visando esse fim, pensei em fazer uma analogia atualizando o que Camillo Penna propôs para analisar o final dos anos 1960 e início dos anos 1970, e a nossa época. Camillo nos confia a seguinte chave de leitura: uma "antinomia entre esquerda e tropicalismo" (PENNA, 2017, p. 46) que, se resumo drástica e simbolicamente, distribuiu Schwarz, de um lado, da "esquerda desconfiada", e Caetano Veloso, de outro, do lado do tropicalismo, do movimento "estético-político-cultural", ${ }^{16}$ insubordinado e irreverente. Poderei traduzir para os nossos dias: uma oposição entre a "esquerda e os movimentos de 2013"? Teremos o direito de comparar? Será que o movimento que tomou as ruas em 2013 pode ser comparado ao "movimento cultural" que se chamou "tropicalismo"? Terão sido a desconfiança e o possível desentendimento - ocorridos entre a esquerda desconfiada e os manifestantes de 2013 - responsáveis pelo indesejável (e agora constatamos horrorizados: catastrófico) avanço da direita e da

${ }^{14}$ Cf. PENNA, J. C. O tropo tropicalista. Rio de Janeiro: Circuito/Azougue, 2017. Neste livro, há uma crítica aguda e contundente à crítica de Schwarz. Poderíamos resumir o livro de Penna a um ensaio crítico da crítica, no qual são revelados os pressupostos hegelianos e marxistas de Schwarz que teriam levado este último a certa incompreensão da "verdade" do Tropicalismo. Verdade essa que nos é brilhantemente desvelada por Penna, como: "uma mistura equidistante entre a adesão afetuosa e a distância crítica" (p. 186), mais uma vez, resumindo bastante.

${ }^{15}$ Esclarecendo o contexto no qual Caetano Veloso se referiu à "esquerda desconfiada", em Verdade Tropical: era mais ou menos 1971, ele estava exilado em Londres e, na sua primeira ida a Paris, seu amigo José Almino lhe dá a conhecer o ensaio de Schwarz, "Cultura e Política, 1964-1969", que se tornaria muito famoso e foi publicado, inclusive, em francês, na revista não menos famosa na época Les temps modernes, de Jean-Paul Sartre.

${ }^{16}$ Assim o definiu em seu Memorial, apresentado para a promoção a professora titular da UERJ, Rosa Maria Dias, que participou ativamente do Movimento Tropicalista, o qual acreditava que "a inovação estética musical já era uma forma por si só revolucionária". 
extrema-direita? Chamo a atenção para os riscos que a esquerda sempre correu e, ao que parece, continua a correr (pergunto com esperança de que, no futuro imediato, estejamos mais do que atentos a esses riscos, a fim de evitá-los!): o de não se unificar e o de não seguir o conselho de esquecer, pelo menos provisoriamente, suas diferenças! Lembro da carinhosa carta recente (15/11/2018) do jornalista Flávio Aguiar a Haddad e Manuela, ${ }^{17}$ aconselhando os candidatos a fugirem "dos debates estéreis, sobre se a frente é popular ou democrática"! Ah, como conhecemos esses debates infinitos (tão comuns na década de 1970) sobre a nomenclatura, os quais só nos dividiram e enfraqueceram! Junto-me a Aguiar e imploro às diferentes e múltiplas esquerdas que tentemos aprender com a experiência do passado e sejamos gratos, como dizia Celan, e "generosos", ${ }^{18}$ como pediu o candidato a presidente pelo PSOL, Guilherme Boulos.

\section{3 "O sequestro da forma"19}

Em junho de 2017, na revista Piauí, Fernando Haddad escreveu o artigo "Vivi na pele o que aprendi nos livros". Ele escreveu:

\footnotetext{
${ }^{17}$ Aguiar (2018): "Vão em frente. Promovam a união dos democratas. Fujam de debates estéreis, sobre se a frente é popular ou democrática, ou sei lá o que mais, como se fossem coisas excludentes e opostas. Resistam à burocratização partidária, sem renunciar à organização dos partidos, mas com pluralidade e multiplicidade. Percorram o país. Abram-se para uma frente internacional e múltipla. Se preciso for, peçam a bênção do papa" (grifos meus).

${ }^{18}$ Numa manifestação na avenida Paulista, logo em seguida ao domingo do $2^{\circ}$ turno, no dia 30/10/2018, Guilherme Boulos propôs a formação de uma frente de esquerda ampla e generosa, que não poderia, de modo algum, excluir um partido como o dos trabalhadores (conforme o desejo anunciado pouco antes pelo também candidato à presidência pelo PDT, Ciro Gomes), mas, em contrapartida, que teria de fugir do "hegemonismo" de qualquer partido, referindo-se implicitamente ao PT. Nesse mesmo sentido foi o artigo do professor de Ciência Política da UFMG, Leonardo Avritzer, publicado na Carta Maior (18 nov. 2018), no qual propõe uma "Frente Democrática Pluripartidária" (grifo meu). A meu ver também, é urgente a formação dessa Frente; e os partidos de esquerda terão de superar seus ressentimentos, revanchismos e, seus membros, suas vaidades pessoais! Pensar generosamente e com gratidão!

${ }^{19}$ Essa feliz expressão foi cunhada por Haddad (2017).
} 
Volto a 2013, de onde parti, para enfrentar a pergunta fundamental se quisermos entender os últimos anos e a situação atual do país: como explicar a explosão de descontentamento ocorrida em junho daquele ano, expressa na maior onda de protestos desde a redemocratização? O desemprego estava num patamar ainda baixo; a inflação, embora pressionada, encontrava-se em nível suportável e corria abaixo dos reajustes salariais; os serviços públicos continuavam em expansão, e os direitos previstos na Constituição seguiam se ampliando (HADDAD, 2017).

Abro aqui mais um parêntese, só para lembrar algumas semelhanças entre o Brasil de 2013 e a França de 1968. Em seguida, retomarei a análise de Fernando Haddad.

Espantada, a França de 1968 também se perguntava: qual o motivo daquelas manifestações de proporções inéditas? O Maio 68 foi um movimento que ocorreu quando a situação econômica na França era de plena prosperidade. No filme de João Moreira Sales (JMS), No intenso agora, assim como no excelente filme Mai 68 - les coulisses de la révolte (Maio de 68 - os bastidores da revolta), ${ }^{20}$ essa observação é repetida, e ouvimos: "A França se entedia", diz a manchete de um jornal. Eram os chamados "30 anos gloriosos". JMS fez referência a isso na sua fala (no dia 30/05/2018 no mesmo evento "68 e depois"): não havia desemprego, a economia avançava a índices chineses, como se diria atualmente. Era o chamado Estado do Bem-Estar Social e, no entanto, aquele movimento queria dizer que, pelo menos, da parte dos manifestantes (majoritariamente jovens, estudantes, secundaristas ou universitários), eles não estavam satisfeitos! Estavam em busca de novos modos de existência. Mesmo assim, não seria correto reduzir o Maio 68 a um movimento somente "comportamental", só do ponto de vista "pueril e superficial dos fatos" (como li na Carta Maior). ${ }^{21}$ Neste ponto, JMS continuou, talvez haja uma relação com as manifestações de

\footnotetext{
${ }^{20}$ Mai 68 - les coulisses de la révolte (Maio de 68 - os bastidores da revolta), obra do jornalista Patrice Duhamel, que também faz a sua narração; foi dirigido por Emmanuel Amara. Esse filme, excelente, em comemoração aos 50 anos do Maio 68, foi exibido na semana entre os dias 7 e 12 de maio de 2018, pelo Canal Cinco francês (TV5), para a América Latina.

${ }^{21}$ Em várias edições, distribuídas por vários dias de maio de 2018, o jornal on-line Carta Maior publicou um denso e aprofundado dossiê sobre Maio 68, sobretudo na França e no Brasil, com a participação de vários intelectuais, jornalistas e políticos.
} 
2013, no Brasil, que também não deixavam de ocorrer, não na "fartura e prosperidade semelhantes à França de 68, mas, dentro dos limites de um país do $3^{\circ}$ mundo, vivíamos um momento econômico-social progressivo". Concordo com JMS, a agenda das manifestações de 2013 não era mais clássica e econômica, era então uma agenda exclusivamente política? Mais do que isso: urbana? Temos o direito de perguntar! Em todo caso, as manifestações evidenciaram uma pauta inadiável, urgente, múltipla e diversificada ou "minoritária":22 diminuição do preço (ou até gratuidade) das passagens de ônibus, LGBT+, feministas, ambientalistas, ecológicas etc. Muito diferentes das pautas das greves de trabalhadores por aumento de salário...

Falta-nos ainda muita análise para clarificar. Faltam-nos conceitos! E vocês poderão perguntar: é importante conceituar? - Talvez não! Em todo caso, temos de compreender... E compreender significa, muitas vezes, conceituar. Desculpem-me, mas, antes de retornar ao artigo de Haddad, apelemos para outra análise, feita há 4 anos e que, de modo premonitório, já avançava no mesmíssimo sentido da de Haddad. Tratase de uma importantíssima entrevista, publicada na revista CULT, em agosto de 2013, feita a Marilena Chaú pelo jornalista Juvenal Savian Filho. Ele perguntou à filósofa sobre a possibilidade de "apropriação pela direita", e ela, apontando para os riscos da falta de rumo do movimento e do pensamento mágico que ela, com razão, intuiu estar na base do fascínio das redes sociais, respondeu:

Essa é a minha preocupação. Há elementos que favorecem a apropriação e a manipulação pela direita: o primeiro é o fato de os manifestantes confundirem o que significa ter uma direção e o que significa ter uma liderança. Como eles se organizam em termos de autogestão e horizontalidade, sem dirigentes e dirigidos, eles identificam ter um rumo com ter um líder. Não percebem que não é a mesma coisa. As manifestações, por enquanto, estão sem rumo; têm palavras de ordem as mais variadas, mas não um rumo, o que as torna frágeis e apropriáveis pela mídia e pela direita. $\mathrm{O}$ segundo elemento é o que eu chamo de pensamento mágico: os manifestantes usaram as redes sociais, ou seja, um instrumento do

\footnotetext{
22 "Minoritária", talvez, no sentido em que Deleuze e Guattari escreveram em Kafka, por uma literatura menor (DELEUZE; GUATTARI, 1977). Voltarei a esse conceito mais adiante, na conclusão.
} 
qual são apenas usuários e de que não tem conhecimento técnico aprofundado nem qualquer controle econômico. As redes estão inseridas numa gigantesca estrutura técnico-científica, econômica e com vigilância e controle geopolíticos (o caso que acaba de ser revelado da espionagem norte-americana sobre todo o planeta não pode ser minimizado), de maneira que, sob a aparência de ser uma alternativa libertária, ela também insere os usuários no mundo do controle e da vigilância. [...] Há ainda um outro aspecto das redes que me pareceu muito claro nas manifestações brasileiras, ou seja, como o usuário não conhece bem o modo de funcionamento das redes, e como para ele basta apertar um botão para que coisas aconteçam, passa-se a ter com a realidade uma relação do mesmo tipo: eu quero, então acontece. Como num ato mágico (SAVIAN, 2013, p. 8-9).

Pedindo de novo desculpas pela longa citação, não posso omitir a reflexão de Chaú, mais uma vez, como um verdadeiro Tirésias, cheia de pressentimento e antevisão, sobre os perigos da supressão de partidos políticos e da reivindicação, feita por muitos participantes das manifestações de 2013, pelo fim da "mediação institucional". Concordo profundamente com Marilena Chauí que este foi um dos terríveis equívocos políticos que terá de ser reconhecido. Como uma vidente, ela continuava em 2013:

Sem nenhuma mediação. Essa relação mágica com a realidade está diretamente relacionada com um elemento poderosíssimo da sociedade de consumo muito usado pelos meios de comunicação: a satisfação imediata do desejo. É uma das raízes da violência, porque anula a mediação, quando, na verdade, o desejo precisa de mediação. [...] Ora, quando se tira a mediação institucional, o que se pede é a ditadura. Por exemplo, quando vi um rapaz enrolado na bandeira brasileira dizer "meu partido é meu país", falei comigo mesma: "É algum neonazista que comanda esse menino, pois esse foi o discurso nazista para a supressão dos partidos políticos!", o que é muito assustador e ainda mais assustador quando uma parte dos manifestantes espancou e ensanguentou manifestantes de esquerda. Eu sempre digo: a crítica aos partidos brasileiros é justificada, a crítica aos governos é justificada, o que não é justificado é não perceber qual a origem desse sistema partidário, qual é a origem desse sistema eleitoral e como é que se luta contra ele. Não se luta suprimindo os partidos, mas produzindo uma nova institucionalidade (SAVIAN, 2013, p. 8-9). 
É muito semelhante o diagnóstico de Leonardo Avritzer (2018), num texto da Carta Maior, no qual o professor de Ciência Política da UFMG não descarta sequer uma aliança, num futuro próximo, com "algumas lideranças de centro do Senado e o STF", visando à formação daquela Frente Democrática Pluripartidária, sem perder de vista as instituições que precisam ser modificadas, mas não suprimidas! Precisamos de "novas institucionalidades" e não o fim delas! É nelas que a democracia se sustenta!

Também preocupado com a fragilidade das instituições brasileiras, das quais toda e qualquer democracia depende, Fernando Haddad escreveu:

Tradicionalmente, todas as modernas organizações contestatórias no Brasil, do Movimento dos Trabalhadores Rurais Sem Terra (MST) ao Movimento dos Trabalhadores Sem Teto (MTST), passando pela Central Única dos Trabalhadores (CUT), pela União Nacional dos Estudantes (UNE) e demais movimentos sociais, sempre foram adeptas de alguma mediação político-institucional. Mesmo durante a fase mais aguda do neoliberalismo, essas organizações faziam atos, exerciam seu direito de protesto, mas buscavam a negociação com as instituições. Diante de governos de centro-esquerda, essa tendência se acentuava e trazia ganhos efetivos para os grupos representados.

Nos países do núcleo orgânico do sistema, onde essa mediação era menos provável, ganhou corpo desde os eventos de Seattle, em 1999, uma certa esquerda antiestatal, neoanarquista charmosa, que mantém distância dos governos e das instâncias de representação política em geral. Os protestos nessas circunstâncias ocorrem de forma inteiramente nova. Sem vínculos partidários nem pretensões eleitorais, a partir de uma agenda bastante específica e de difícil contestação, esses movimentos começaram a fazer sucesso mundo afora. E eles foram bastante críticos em relação à política e às formas tradicionais de negociação, que viriam inspirar os movimentos mais contemporâneos que se desenvolveram no Brasil, dentre os quais o Movimento Passe Livre (MPL).

No intervalo de uma semana as ruas estavam cheias, com uma pluralidade de reivindicações desconexas e às vezes contraditórias entre si. Quando o sequestro da forma se consumou, o MPL se retirou das ruas, bem como a esquerda tradicional caudatária do movimento. E grupos de direita, apartidários, se organizaram para emparedar o governo federal, apropriando-se sintomaticamente da 
própria linguagem dos protestos originais, que ganhavam simpatia popular: MBL (Movimento Brasil Livre) é uma corruptela de MPL; Vem Pra Rua era um dos gritos mais ouvidos nos protestos; Revoltados On Line evoca diretamente a natureza daqueles eventos convocados via rede social (HADDAD, 2017).

Contribuindo para esta tentativa de análise da nossa estranha conjuntura, apelo também para o livro de Leonardo Avritzer (2016) - sobre os impasses da democracia brasileira, o qual expõe de modo minucioso as manifestações de junho de 2013! Elas foram examinadas quase dia a dia pelo autor: desde o início do mês de junho até o dia 17 e, depois, do dia 21 ao 30, e assim por diante. Além disso, ele analisa as diferenças entre as principais cidades brasileiras: São Paulo, Rio de Janeiro e Belo Horizonte. Numa narrativa sintonizada com a de Haddad, sobre o "sequestro da forma", Avritzer nos mostra como tudo mudou no decorrer do mês de junho de 2013. Tomando como base a plataforma Causa Brasil,, "que sistematizou os dados de mais de 1,2 milhão de postagens nas redes sociais", ele conclui que "as principais demandas no dia 7 de junho eram: preço das passagens, democracia, qualidade do transporte público, postura da polícia e governo Dilma Roussef" (AVRITZER, 2016, p. 75). A partir da terceira semana de junho, ocorre um "divisor de águas na política brasileira", no momento em que se "instala uma agenda ofensiva em relação ao governo Dilma que não reflui mesmo após a reeleição dela, em outubro de 2014, e é reforçada a partir de março de 2015" (AVRITZER, 2016, p. 81). E, assumindo a agenda da corrupção, a direita conservadora que, desde 1964, estava praticamente afastada das ruas, volta às ruas. Confirmando essa análise, o autor ainda faz um brevíssimo "diagnóstico das manifestações de março de 2015" (AVRITZER, 2016, p. 81-82), e indica o crescimento da participação da classe média: de 23\% em 2013 para 41\% em 2015, ou seja, aconteceu o que o professor Rogério Lopes já estava há muito nos prevenindo: "a direita tomou gosto de ir para as ruas!"24 Ainda em 2013, Marilena Chaú, profética, caracterizara áspera, mas agudamente, esta classe média que iria protagonizar as manifestações de rua de 2015, por

\footnotetext{
${ }^{23}$ www.causabrasil.com.br apud AVRITZER, 2016, p. 75.

${ }^{24}$ Cito a advertência do meu colega, o professor Rogério Lopes, do departamento de Filosofia da UFMG, repetida tantas vezes por ele a seus alunos, entusiasmados participantes das manifestações de 2013.
} 
meio de "três abominações: a política, porque é fascista; a abominação ética, porque é violenta; e a abominação cognitiva, porque é ignorante" (SAVIAN, 2013, p. 12-13). Segundo a filósofa, a classe média "grita contra o efeito daquilo que Golbery ${ }^{25}$ fez como se fosse obra do PT" (SAVIAN, 2013, p. 13). O que ninguém poderia imaginar em 2015 (e muito menos em 2013) foi o que aconteceu em outubro de 2018! Esse mesmo grupo das "três abominações" conseguiu eleger seu candidato ultradireitista, com o evidente apoio jurídico-midiático-policial e de uma parte do povo desiludido-iludido.

\section{4 "Ofensiva constante"}

Que me desculpem os organizadores do evento e a plateia se adio ainda a tarefa de comentar o filme e sucumbo ao chamado mais urgente e politicamente preocupado do polêmico paralelo entre 1968 e 2013. Será que, em ambos os casos, na França e no Brasil, podemos diagnosticar um fracasso da esquerda? Pois, não é impossível ler na história do movimento de Maio 68 francês uma certa narrativa: a de que ele acabou no dia 30 de maio... Como nos permite interpretar Edgar Morin:

Maio 68 foi uma peça em dois atos. O primeiro começa nos confins de um subúrbio parisiense, onde uma universidade, a de Nanterre, pega fogo. E o fogo se espalha a Paris, à Sorbonne, a Saint Germain de Près, à juventude operária. A "intelligentsia", essa nova "intelligentsia" dos rádios e dos jornais, entra no movimento. Em seguida, são os sindicatos que por sua vez aderem e, finalmente, toda a nação entra subitamente num estado de paralisia.

O segundo ato começa em junho. O seu ponto de partida é o discurso do General de Gaulle, ao qual se seguem eleições que asseguram o triunfo da direita e, em poucos dias, tudo acaba como se nada tivesse acontecido. Se a dramaturgia de Maio 68 é límpida, o acontecimento não é claro. É um acontecimento multidimensional, representado por atores que juntamos na condição de "gauchistes", que estão realmente unidos na ação, mas que na realidade são muito diferentes (MORIN, 2008, p. 29).

${ }^{25}$ Golbery do Couto e Silva foi ministro-chefe do Gabinete Civil do Brasil dos governos militares entre 1974 e 1981. 
Sim, no dia 30 de maio, De Gaulle faz um terrível e ofensivo discurso. Ele, que tinha sumido no dia anterior, por algumas horas, deixando seus ministros, inclusive Georges Pompidou - que se tornaria em seguida (1969) presidente da República, mas que era na época o primeiro ministro de De Gaulle -, totalmente atônitos, desesperados! Cito: "sem prevenir a ninguém, de Gaulle foi à Alemanha, consultar seu antigo companheiro de luta, o general Massu, ao invés de ir para a sua outra casa, em Colombey, como anunciara oficialmente!" (WIKIPEDIA, 2018). ${ }^{26} \mathrm{De}$ volta a Paris, aceita a proposta de Pompidou, de dissolver a Assembleia Legislativa e convocar novas eleições. Esse discurso agressivo que De Gaulle transmitido pelo rádio foi apoiado por 300 mil pessoas, ouvindo radinhos de pilha, marchando pela avenida Champs Elysées. André Malraux estava entre os organizadores dessa marcha. Para finalizar essa possível leitura dos acontecimentos de Maio 68 em Paris, teríamos de concluir dizendo que não durou mais do que um mês aquela aliança tão promissora que se estabeleceu entre os estudantes (secundaristas que tiveram papel excepcional pela primeira vez, como nos contou o filme por meio daqueles Comitês de ação dos secundaristas [CAL] que estavam organizadíssimos e "prontos" para as manifestações que, na realidade, começaram na Universidade de Nanterre, no movimento "22 de março", liderado por Cohn-Bendit) e os operários, que fizeram uma das maiores greves da história: 10 milhões de trabalhadores que pararam a França? Movimento que, ainda segundo a opinião de Edgar Morin, "nada mudou e, no entanto, tudo mudou". ${ }^{27}$ Nada pareceu mudar na superfície, pois

\footnotetext{
${ }^{26}$ Numa entrevista a Michel Droit, em 7/06/1968, De Gaulle declarou: "No dia 29 de maio, tive a tentação de me retirar. Depois, ao mesmo tempo, pensei que se eu fosse embora, a subversão que crescia de modo assustador iria devastar (défeler) e destruir a República. Então, mais uma vez, tomei a decisão [de voltar]."

${ }^{27}$ MORIN, 2008, p. 33: "A partir do momento em que De Gaulle dominou a situação, e após as eleições reconduzirem à Assembleia Nacional uma forte maioria conservadora, tudo voltou aos seus lugares. Os partidos políticos se recompuseram, o Estado se reencontrou em suas estruturas e, mesmo no domínio econômico, a crise foi superada no período de um outono. Insistiram tanto que a economia francesa havia sofrido um golpe fatal, por causa da paralisação de um mês e por causa dos aumentos de salários arrancados pelos sindicatos e, no entanto, nada disso ocorreu. Pelo contrário, a economia saiu purgada do episódio e recomeçou a funcionar em pleno vapor. As coisas se recompuseram por toda a parte e, no entanto, abaixo da superfície social, tudo mudou."
} 
tudo voltou ao normal: as fábricas, as escolas etc., mas ao mesmo tempo, profundamente, tudo havia mudado...

E no Brasil de 2013, terá sido invertida a fórmula de Morin? Tudo terá mudado na superfície, mas nada profundamente?

Mesmo reconhecendo que foi nas passeatas de junho de 2013 que alguns movimentos sociais se articularam (ou foram "reafirmados", como foi o termo usado por JMS na entrevista publicada no Correio Brasiliense) e ocuparam as ruas, movimentos tais como: dos LGBTs, dos negros, das mulheres, dos secundaristas, dos defensores dos povos indígenas, dos ambientalistas, eu desconfiei e não fui às ruas! Mais do que isso, talvez assumindo a posição de uma "esquerdista desconfiada" (lembrando o rótulo através do qual Caetano Veloso chamou Roberto Schwarz em 1971), critiquei muitas vezes o meu filho por delas participar. Houve muitas discussões acaloradas dentro de casa, um verdadeiro conflito de gerações! O dualismo e os opostos repetindo-se dentro de casa, dividindo-nos: de um lado, meu filho, manifestante em 2013, fazendo novos questionamentos contra as estruturas escravocratas, racistas, machistas da nossa sociedade; do outro lado, da esquerda "mais antiquada", "desatualizada"(?); eu mesma e meu companheiro, resistindo, não aceitando o fato de instabilizarem um governo que, se já não podíamos mais chamar de "esquerda" (muita gente já questionava, com razão, a política econômica do governo Dilma), por outro lado, todos sabiam que, desde Getúlio Vargas, os governos do PT tinham sido os únicos, a se preocuparem com o social, com o problema da fome (inadmissível!), da miséria e da desigualdade.

Portanto, em 2013, não tivemos dúvida, meu marido e eu mesma nos posicionamos contra as manifestações. Talvez, essa tenha sido uma atitude equivocada, segundo a provável opinião da maioria da plateia aqui presente. Talvez, se a esquerda estivesse unida lá, naquele momento, não estaríamos vivendo hoje essa derrota infame e vergonhosa. Não sei! Penso que não cabe procurar culpados! Até porque a verdadeira culpa não está nas manifestações de 2013 (e é importante não perdermos isso de vista!), o nosso verdadeiro inimigo ontem, hoje e amanhã era, é e será sempre a direita neo-liberal, conservadora. Aquela que já estava se organizando e nunca poderíamos imaginar, nem mesmo em maio de 2018, que ainda teríamos de nos haver com uma extrema-direita capaz de articular - ainda que à custa de muita fraude, embotamento e mentira - a vitória que obteve nas urnas. E muitas pessoas de esquerda, como Marilena Chauí ou meu 
amigo Rogério Lopes, já estavam prevendo, talvez não na dimensão que a realidade provou ser possível, a catástrofe que ocorreu. No filme de Goupil, vimos também como as manifestações fascistas em 1969, em Paris, se acirraram! O narrador nos fala da necessidade de um alerta, de uma ofensiva constante: "A atividade da extrema-direita exigia uma constante ofensiva: nas faculdades, nos liceus, nas ruas, em toda parte! Tentávamos esmagar a peste castanha na origem (no ovo)."

No meio da discussão, era inevitável aceitar a afirmação de Pedro Veras, de que aqueles movimentos citados (negros, mulheres, LGBTs) tinham adquirido uma grande visibilidade nas manifestações de 2013. E em política, sem dúvida, visibilidade significa muita coisa. Pois, modificando um pouco a célebre expressão de Jacques Rancière, inspirada por Hannah Arendt, além do "mundo da arte", é somente no mundo político, onde vigora a antiga ontologia, que se afirma: "ser é aparecer". Então, é muito importante, "aparecer", vir à tona. Não é à toa que chamamos "manifestação" ao "conjunto de pessoas que se reúnem em lugar público (e o grifo é meu) para defender ou tornar conhecidos seus pontos de vista, suas opiniões", segundo a definição do Houaiss (2001). Ninguém há de questionar que houve um avanço, pelo menos em termos de reconhecimento e ampliação da consciência social e política, de movimentos como o dos Sem Terra ou o dos Trabalhadores Sem Teto. É inegável! Hoje, não será mais possível fazer política sem levar em conta todos esses aspectos da nossa sociedade, que, além de exploradora capitalista do trabalho, é racista, patriarcal, machista, colonialista, destruidora do meio ambiente e assim por diante. Então, a pauta política, digamos assim, complexificou-se, e muito! E 2013 não deixou de escancarar essa complexificação!

Continuando o diagnóstico, apesar de todas essas conquistas dos movimentos, digamos, singulares (a fim de contrapô-los aos universais e mais econômico-sociais), os quais, segundo minha amiga mais otimista entre todas, professora de filosofia da UFOP, Imaculada Kangussu, a Leca, são (ou se tornaram) irreversíveis! Segundo ela (como Kant, em 1789!), nós vamos caminhar para o melhor! (Melhor, Leca?!) Apesar de todas essas conquistas, quero crer junto com a Leca: irreversíveis, infelizmente, como disse o jornalista Breno Altman: "a direita saiu do armário" ou "saiu do tubo (como o da pasta de dentes) e enfiar de novo no tubo o que já se esparramou pelo chão... Será que conseguiremos?" (TV 247 YouTube) Perguntou-se o mesmo jornalista, e ainda era maio 
de 2018... E agora, uma vez o golpe (Temer) iniciado, fica difícil! Como todo mundo já sabe! Um golpe moderno, institucional, jurídicomidiático-policial! Mas não vou continuar a falar dele, de todas as nossas perdas sociais, políticas, institucionais etc., para não nos deprimirmos! Vou evitar a melancolia, que parece ser o humor tradicional e histórico das esquerdas que, num certo sentido, sempre saem perdendo! ${ }^{28}$ Sempre ficamos com aquele gosto amargo da derrota! A revolta em 2013 não deu certo! Mas o "evento absoluto" do maio 1968, também não deu! Como num surto bi-polar, saímos das manifestações de 2013 com o ânimo elevado, entusiasmados, "maníacos", se quiséssemos empregar o vocabulário das psicopatologias. Saímos histórica e politicamente, quase sem escala, para a fase depressiva, melancólica, da perda da alegria, do entusiasmo, e o pior de tudo: da esperança! Porém, lembremos que o olhar retrospectivo e sóbrio, já "comprometido com a teleologia histórica", é sempre e necessariamente melancólico; o olhar retrospectivo perde (no tempo entre o passado e o presente) exatamente aquele "elemento utópico da revolta" (cf. PENNA, 2017) ${ }^{29}$

Como definiu a Carta Maior (em 10/05/2108), escrevendo sobre o filme documentário já citado aqui, para alguns, Maio 68 foi “uma ruptura na história do século XX, [um] movimento libertário inspirado em sua origem pelo anarquismo, uma revolução típica contra o capitalismo, contra o consumismo e contra a educação elitista." Para outros, ao contrário, como o sociólogo francês, Geoffroy Lagasnerie (2018), o Maio 68 promove "um sentimento estranho" e até "um mal-estar". Ele confessa que sente "uma espécie de ódio do presente nesses elogios a Maio", chega a dizer que há uma fetichização do Maio de 68 e que ela "corresponde a aprisionar o presente no passado, como se a política fosse

\footnotetext{
${ }^{28}$ Lembrando da frase de Darcy Ribeiro que foi citada de modo recorrente nas redes sociais (WhatsApp) nos últimos tempos: "Fracassei em tudo que tentei na vida. Tentei alfabetizar crianças, não consegui. Tentei salvar os índios, não consegui. Tentei uma universidade séria, não consegui. Mas meus fracassos são minhas vitórias. Detestaria estar no lugar de quem venceu."

${ }^{29}$ Parafraseio os termos por meio dos quais o autor analisa o narrador de Verdade Tropical (p. 186): "A avaliação posterior esfria o elemento utópico da revolta ao lhe acrescentar um viés realista e sóbrio, que ao mesmo tempo lhe faz perder o essencial do tempo em que se deu [..] é sempre a proposição vanguardista que parece juvenil e ingênua, diante de um olhar retrospectivo que se quer mais comprometido com uma teleologia histórica estabelecida" (grifo meu).
} 
imóvel, [como] se enfrentássemos sempre os mesmos inimigos abstratos: 'o capitalismo', ‘o Estado'.” E continua:

então esquecemos completamente que os sistemas de poder são históricos e que as lutas se transformam. Imaginamos às vezes que a referência a Maio de 68 nos traz energia e esperança. $\mathrm{Na}$ verdade, ela pode mutilar as lutas de hoje, nos impedir de perceber que o mundo se transformou. Ao elogiarmos aquela época, nos comportamos como se não vivêssemos no presente. Ou seja, os elogios mutilam a nós mesmos.

Concordo com Lagasnerie que os movimentos são totalmente distintos, as pautas são completamente diferentes, no entanto, acho que não nos imobiliza pensar sobre Maio 68 (fetichizamos? - Talvez... Mas isso não nos mutila!) Acho que podemos contar a história das insurreições, dos conflitos, seguir a famosa ideia de Walter Benjamin, de contar a história a contrapelo - do ponto de vista daqueles que foram derrotados - da perspectiva da esquerda, que talvez seja mesmo a tendência que nunca se impõe de modo definitivo ou duradouro, até porque, aberta às mudanças, ela pode levar rasteiras históricas, como foram certamente os casos de 1968 e de 2013. Não falo de outros movimentos porque não conheço! Em 68, de um dia para o outro, de 29 a 30 de maio, o movimento virou. De Gaulle, com a ajuda, claro, da centro-direita que também estava organizada, virou a história a seu favor. Quando ninguém mais acreditava na possibilidade de uma restauração do seu governo, De Gaulle resgata sua autoridade. É verdade que, por pouco tempo, pois, menos de um ano depois, ele foi derrotado num plebiscito e obrigado a deixar o governo, mas, de qualquer modo, Pompidou (candidato gaullista) foi eleito em 1969.

No filme, a história do discurso de De Gaulle e da "volta ao normal" não nos é relatada. Para Romain Goupil e uma poderosa vertente dos participantes do Maio 68, o movimento não acabou no 30/05/1968, mas sim, noutro junho, cinco anos depois: precisamente, no dia 21 de junho de 1973, o dia da virada (tournant), o dia em que "tudo mudou". Romain, que é o narrador do filme, conta-nos que, nesse dia, foi dissolvida e proibida a Liga Comunista (fusão dos partidos Juventude Comunista Revolucionária e do Partido Comunista Internacionalista, fusão essa ocorrida em abril de 1969, na Alemanha); e Michel Recanati foi considerado um dos responsáveis. Ele tentará exilar-se no exterior, 
mas acabará preso por três meses. O filme ainda narra que, a partir de maio de 1973, as campanhas racistas e antissemitas haviam recrudescido. Michel Recanati aparece avisando sobre a preparação de um comício fascista em Paris. A música que acompanha essas imagens é a Abertura de Guilherme Tell de Rossini. O comportamento de Michel já é descrito, neste momento, como "hesitante". Alguém que não sabia mais se queria continuar a militar. Os acontecimentos se precipitam e não há mais imagens correspondentes. Ficamos apenas sabendo, por meio do relato de outro amigo (Sylvain), que Michel foi procurar trabalho e se tornou bancário! Ou ainda que o amigo o tentara convencer a fazer um concurso para entrar na Escola de Ciências Econômicas. Outras informações nos são dadas sobre a mulher de Michel, Monique, sobre sua doença e morte. O filme acaba com a música de Rossini, mais uma vez: La gazza ladra.

\section{Conclusão}

Antes de concluir este ensaio decepcionante, por vários motivos, principalmente pela ausência de comentário efetivo ao filme de Romain Goupil, queria, em primeiro lugar, pedir desculpas e, em seguida, voltar ao tema da alegria intensa que senti durante o filme, apesar de seu triste título, Mourir à trente ans. Creio ter sido a forte alegria também o sentimento que caracterizou o Maio 68 na França, segundo a magnífica descrição de Edgar Morin:

Maio de 68 foi vivido como uma grande festa, como um jogo. Dizse que foi a tomada da palavra. Toda a rua falava. Um dos meus amigos médicos ainda me lembrou isso recentemente. Em maio os consultórios médicos ficaram vazios. Todas as pequenas doenças, as crises de fígado, as dores nas costas, tudo isso desapareceu. Em contrapartida, desde o retorno de poder do estado, as pessoas reencontraram as suas misérias e os consultórios médicos encheram-se de novo. Lembro-me bem que eu próprio conheci um momento de saúde perfeita. Dormia apenas três horas por dia e não tinha necessidade do meu refúgio, o sono.

O fenômeno notável é que a paralisia do poder social se traduziu numa alegria dos indivíduos. Tudo se passou como se em períodos normais cada um fosse inibido; não apenas oprimido como também aflito. Maio de 68 foi sentido como "férias", e uso essa palavra em seus dois sentidos: um vazio na teia dos dias que se transformou em férias, festa e em liberdade. E o mais importante 
é que esse estado foi vivido não só pelos estudantes, mas nas primeiras semanas, por toda a cidade grande, Paris. A alegria estava nas ruas e nela ficou até o momento em que a angústia chegou. A angústia sentida por uma parte crescente da população diante do acúmulo de lixo. Da falta de alimentos, da penúria de combustível, dos saques e da queima de automóveis. À alegria da supressão da ordem sucedeu o medo da desordem (MORIN, 2008, p. 30).

Tenho me perguntado, última e insistentemente: não terá sido aquela alegria contagiante do "evento absoluto", que foi o Maio 68 no mundo, mas mais especificamente na França, o que pôs a pensar toda a geração, talvez, entre as mais prolíficas, de pensadores, e acima delas e deles todos, Gilles Deleuze \& Félix Guattari? Não terá sido para compreender ${ }^{30}$ o Maio 68 que esta geração se pôs a pensar e criar seus conceitos, tais como "micropolítica", "menor", "rizoma", "ligação do individual no imediato-político" e "agenciamento coletivo de enunciação"? ${ }^{31}$ Em contrapartida, terão desejado, pelo menos, os "primeiros" manifestantes de 2013 no Brasil, experimentar os "modos de existência", sempre intensos e alegres, da festa política anunciada por aqueles mesmos conceitos?

\section{Agradecimentos}

Agradeço à Natacha e ao Pedro Rena pelo gentil convite; em seguida, ao Cineclube Humberto Mauro pela oportunidade, acolhida e iniciativas culturais que vem realizando e que são tão importantes para o povo belo-horizontino. Finalmente, chegando à UFMG, agradeço ao Grupo de Pesquisa, cujo nome magnífico merece ser mencionado: "Indisciplinar", e ao professor Eduardo Soares, meu colega de departamento, com quem tive a honra de compartilhar a mesa "Revolta e Melancolia".

\footnotetext{
${ }^{30}$ Qual será a maior tarefa da filosofia senão a de, em última instância, compreender? Volto à sábia Marilena Chauí, na entrevista já citada (SAVIAN, 2013, p. 11): "para quem viu a disputa desigual pelo direito à rua entre os manifestantes de esquerda e de direita, talvez valha a pena lembrar o que escreveu Espinosa: não rir, não lamentar, não detestar nem compactuar, mas compreender."

${ }^{31}$ DELEUZE; GUATTARI, 2015, p. 39: “As três características da literatura menor são a desterritorialização da língua, a ligação do individual no imediato-político, o agenciamento coletivo de enunciação."
} 


\section{Referências}

AGUIAR, F. Carta de Berlim: carta aberta ao companheiro e colega Fernando Haddad e à Manuela. Carta Maior, on-line, 17 nov. 2018.

AVRITZER, L. Como ser oposição ao governo Bolsonaro pela esquerda e pelas forças democráticas. Carta Maior, on-line, 19 nov. 2018.

AVRITZER, L. Impasses da democracia no Brasil. Rio de Janeiro: Civilização Brasileira, 2016.

DELEUZE, G.; GUATTARI, F. Kafka, por uma literatura menor. Tradução de Júlio Castañon Guimarães. Rio de Janeiro: Imago, 1977.

DELEUZE, G.; GUATTARI, F. Kafka, por uma literatura menor. Tradução de Cíntia Vieira da Silva. 1 ed., 2. reimp. Belo Horizonte: Autêntica, 2015.

HADDAD, F. Vivi na pele o que aprendi nos livros. 2017. Disponível em: https://piaui.folha.uol.com.br/materia/vivi-na-pele-o-que-aprendinos-livros/. Acesso em: 20 nov. 2018.

HÖLDERLIN, F. Observações sobre o Édipo. In: MACHADO, Roberto (org.). Hölderlin \& Beaufret. Tradução de Pedro Süssekind. Rio de Janeiro: Jorge Zahar, 2008.

HOUAISS, A. et al. Dicionário eletrônico Houaiss da língua portuguesa. Rio de Janeiro: Objetiva, 2001. 1 CD-ROM.

KANT, I. Kritik der reinen Vernunft (B: 421). Crítica da Razão Pura. Tradução de Valério Rohden e Udo Baldur. São Paulo: Abril Cultural, 1980.

LAGASNERIE, G. Jornal do Brasil, on-line, 31 maio 2018.

MORIN, E. O jogo em que tudo mudou. In: COHN, Sérgio; PIMENTA, Heyk. Encontros de Maio de 68. Rio de Janeiro: Beco do Azougue, 2008.

PENNA, J. C. O tropo tropicalista. Rio de Janeiro: Circuito/Azougue, 2017.

PESSOA, P. Sísifo infeliz No intenso agora. Revista Viso - Cadernos de Estética Aplicada, $n^{\circ}$ 23, 2018. Doi: https://doi.org/10.22409/19814062/v23i/272. Disponível em: http://revistaviso.com.br/visArtigo. asp?sArti=272. Acesso em: 28 jan. 2019. 
SARTRE, J. P.; COHN-BENDIT, D. A ampliação do campo do possível. In: COHN, Sérgio; PIMENTA, Heyk. Encontros de Maio de 68. Rio de Janeiro: Beco do Azougue, 2008.

SAVIAN, Juvenal. Pela responsabilidade intelectual e política. Entrevista a Marilena Chauí. Revista CULT, n. 182, ago. 2013.

VIVEIROS DE CASTRO, E. Metafisicas Canibais - elementos para uma antropologia pós-estrutural. São Paulo: Cosac \& Naify, 2018.

WIKIPEDIA. Verbete Maio 68. Disponível em: https://fr.wikipedia.org/ wiki/Mai_68\#Le_basculement. Acesso em: 2 maio 2018.

Recebido em: 23 de março de 2019 Aprovado em: 9 de maio de 2019 